\begin{tabular}{lc}
\hline CURRENT & ISSN: 0973-4929, Vol. 13, No. (3) 2018, Pg. 288-291 \\
WORLD & Current World Environment \\
ENVIRONMENT & Journal Website: www.cwejournal.org \\
\hline
\end{tabular}

\title{
Freshwater Shortage and Arrangement by Modern Technology
}

\author{
MOHAMMAD OVES ${ }^{1,2 *}$ \\ ${ }^{1}$ Centre of Excellence in Environmental Studies, King Abdulaziz University, Jeddah, KSA, 21589 \\ ${ }^{2}$ Department of Biological Science, King Abdulaziz University, Jeddah, Makkah, KSA, 21589
}

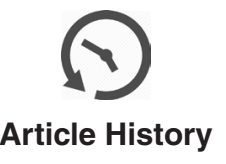

Received: 22 November 2018

\begin{abstract}
A water molecule is an atomic ratio 2:1 of hydrogen and oxygen atom while according to mass 1:8 ratio of hydrogen and oxygen, it is an odourless and tasteless solution that is fundamentally present in waterways, streams, lakes, ocean, in every single living being, and the atmosphere. It is the principal constituent of Earth and is available in multiple forms. It is the necessary source of all living and non-living things other than any natural supplements. It circles persistently as disappearing, transpiration buildup, precipitation, lastly reaches to the ocean. According to the National Ground Water Association (NGWA), the earth is a "Blue Planet" because Earth's surface covered up to $71 \%$ water. Interestingly, only $0.3 \%$ of these waters are used for humans and remains $99.7 \%$, the abundant amount is unusable and reserved for natural resources and floating in the atmosphere. ${ }^{1}$ NGWA suggested the water is distributed in the Ocean $(97.2 \%)$, ice caps and glaciers $(2.15)$, groundwater $(0.61 \%)$, Freshwater lakes $(0.009 \%)$, inland seas $(0.008 \%)$, soil moisture $(0.005 \%)$, floating in the atmosphere $(0.001 \%)$ and in the rivers $(0.0001 \%)$ on Earth. ${ }^{1}$ While the majority of freshwater comes from the rivers, lakes, groundwater, these natural resources contain a very limited amount of freshwater water and it is shrinking and contaminated days by day due to anthropogenic activities. Angelina Davydova reported the world largest freshwater Lake Baikal is shrinking and other lake also under environmental threat. ${ }^{2,3}$ Aarhus University researchers (2014) have combined the results from the research projects and reveals the drinking water scarcity up to 30 to $40 \%$ in many regions worldwide in 2020. ${ }^{4}$ According to the U.S. Intelligence Community Assessment of Global Water Security, by 2030 humanity's "annual global water requirements" will exceed "current sustainable water supplies" by $40 \% .^{5}$ However, in Indian freshwater demand become hike and reached up to 1.5 trillion cubic meters, approx 21 Indian cities' water will run out and $40 \%$ people may not be able to drink pure water by $2030 .{ }^{6}$
\end{abstract}

CONTACT Mohammad Oves $\$$ owais01m@gmail.com 9 Centre of Excellence in Environmental Studies, King Abdulaziz University, Jeddah, Saudi Arabia.

\section{(c) (i)}

(c) 2018 The Author(s). Published by Enviro Research Publishers.

This is an Open Access article licensed under a Creative Commons license: Attribution 4.0 International (CC-BY).

Doi: http://dx.doi.org/10.12944/CWE.13.3.02 
The broad measure of water-related to mineral (as the pool of hydration) is viewed as fundamental for the verdure. Dumping of mechanical wastewater ( $80 \%$ of the world's wastewater) to the natural water assets has turned into the primary source of water contamination. Utilization of contaminated or toxin containing water causes various illnesses in individuals and creatures.

Worldwide the $>1.2$ billion population are confronting the issue of safe drinking water while more than 2.8 billion peoples have affected the water shortage one month annually. ${ }^{7}$

In an ongoing situation, it is foreseen that because of the rising global population $\sim 9.7$ billion, by 2060 immense water emergency related issues (lack of fresh water) will be seen everywhere throughout the world. ${ }^{8}$ In this manner, it turns into a vital undertaking to treat contaminated water before releasing into natural water assets. Accordingly, treatment of water has been done utilizing various strategies and materials, for example, filtration, natural treatment, photo-catalysis, thin film technology, sun-powered purification, oxidation precipitation, electrolysis, turns around assimilation, biodegradable nanocomposite, materials for adsorption and so on. ${ }^{9-12}$ Be that as it may, adsorption is observed to be the most flexible strategy attributed to its simplicity of the task, minimal effort, and high proficiency. The choice of the adsorbent is by, and large was based on high selectivity, cost-viability and also generous adsorption limit. Also, non-toxic conduct and recovery limit of adsorbents together with zero waste/ooze generation have been pulled in adsorbents in water treatment. There have been enormous increments in the number of research papers published on adsorption, but more work is still expected to enhance adsorption limit and regenerative capability of depleted adsorbents. Nowadays, the most vital responsibility of the exploration network is to create innovative, financially savvy, dependable strategy for the investigation and additionally expulsion of environmental contaminants. ${ }^{13}$ In the present scenario worldwide, numbers of researchers and engineers are working on to manage the fundamental standards and methods, including reuse, boosted methods of water treatment.

Furthermore, water free from bacterial contaminants and improvement of water treatment plants by applying Nano-composite materials. ${ }^{14,15}$ Alumina-based nanofiber has been utilized for the treatment of adversely charged polluting influences (microscopic organisms, Virus, natural/inorganic colloids). In future nanotechnological approaches will be the best way of water treatment in a sustainable manner with rapid and inexpensive. Nanomaterial actualized devices, incorporates carbon nanotubes-alumina filaments, nanoscopic pores in the zeolite filtration layer, polymer nanocomposites including directing and nonconducting polymers, nanocatalysts, attractive nanoparticles will be used in purification of water. Other than water treatment, nanotechnology can be utilized for the expulsion and recuperation of blend effluents, pathogens, microbes, waste residues, thick fluid polluting influences, and so forth. In the future, it is accepted that of nanomaterial-upheld water treatment devices can endorse novel nanohybrid materials. Treatment of modern wastewaters by utilizing nanohybrid thin films is another development activity. ${ }^{16}$ Diverse kinds of films have been utilized to enhance water quality. Layer technology has been successfully utilized to examine sulphate based pollutions. A considerable measure of work is done to create a nanocomposite film and sensing materials. ${ }^{16-19} \mathrm{Be}$ that as it may, a few issues in regards to vitality productivity, fouling attributes of the layer must be made plans to acquire a sustainable power source related to film technology. Till date layer technology has been created as an unflinching savvy technology for the water treatment. To use frequently available assets, treatment of wastewater contaminants utilizing bioremediation strategy is another intriguing subject which was talked about in detail already in the literature.

In the present scenario, management of wastewater treatment by utilizing natural treatment technology to control water contamination and keep away each animal and human being from water conceived infections. It new focuses, on the evacuation and recuperation of natural and inorganic contaminants from wastewater through the composite and nanocomposite materials. ${ }^{20-22}$ Sanitizations of wastewater utilizing sunlight based vitality and the photolysis and catalytic reaction is another fascinating tool. Chitosan-based nanocomposites 
are also beat material for investigation of natural pollutants de-contaminations. ${ }^{23}$ To reuse, mechanical effluents, savvy, eco-accommodating power module technology is more successful. Into the wrap things up, the present title covers cutting-edge innovations which have been adequately utilized in present day's wastewater treatment.

\section{References}

1. Nace. USGS and The Hydrologic Cycle (Pamphlet), USGS, 1984, http://ga.water.usgs.gov/edu/ earthwherewater.html). 1967.

2. A Davydova. Reuters News, (https://www.businessinsider.com/r-in-russia-a-drying-lake-threatensan-era-of-water-wars-2015-3). 2015.

3. C Kozacek. Biggest Lakes in the World Under Pressure From Human and Environmental Threats, Africa, Asia, California, Climate Change, Europe, Great Lakes, Latin America, Middle East, North America, Water News /by (https://www.circleofblue.org/2015/world/biggest-lakes-in-the-world-underpressure-from-human-and-environmental-threats/). 2015.

4. $\quad$ Aarhus University, "Worldwide water shortage by 2040." ScienceDaily. ScienceDaily, 29 July 201. 2014.

5. S. M Patrick. The Coming Global Water Crisis, https://www.theatlantic.com/international/ archive/2012/05/the-coming-global-water-crisis/256896/. 2012.

6. A Shukla. Alarming: 21 Indian Cities Will Run Out Of Water By 2030, BW Business (http://www.businessworld.in/article/Alarming-21-Indian-Cities-Will-Run-Out-Of-WaterBy-2030/19-06-2017-120383/. 2018.

7. https://www.sciencedaily.com/terms/water_scarcity.htm

8. E Luxton. https://www.weforum.org/agenda/2016/09/the-countries-with-the-biggest-populations-from1950-to-2060/. 2016.

9. A. A. P Khan., A Khan., M. A Alam., M Oves., A. M Asiri., M. M Rahman. Chemical sensing platform for the $\mathrm{Zn+2}$ ions based on poly(o-anisidine-co-methyl anthranilate) copolymer composites and their environmental remediation in real sample. Environmental Science and Pollution Research 25 (28), 27899-27911. 2018.

10. M Arsalan., M. A Khan., I Khan., M Oves. Synthesis and electrochemical behaviour of polyvinyl chloride-based Tin (IV) TungstoArsenate composite membrane for purification of aqueous contaminated electrolyte solutions. Groundwater for Sustainable Development. 2018;7:483-489.

11. R Bushra., T Arfin., M Oves., W Raza., F Mohammad., M. A Khan., A Ahmad. Development of PANI/ MWCNTs decorated with cobalt oxide nanoparticles towards multiple electrochemical, photocatalytic and biomedical application sites. New Journal of Chemistry. 40(11):9448-9459

12. M Anjum., M Oves., R Kumar., M. A Barakat. Fabrication of ZnO-ZnS@ polyaniline nanohybrid for enhanced photocatalytic degradation of 2-chlorophenol and microbial contaminants in wastewater. International Biodeterioration and Biodegradation. 2017;119:66-77.

13. T Weldeslassie., H Naz., B Singh., M Oves. Chemical Contaminants for Soil, Air and Aquatic Ecosystem. Modern Age Environmental Problems and their Remediation. 2018;1:1-22.

14. R Bushra., M Shahadat., A Ahmad., S. A Nabi., K Umar., M Oves., A. S Raeissi. Synthesis, characterization, antimicrobial activity and applications of polyanilineTi (IV) arsenophosphate adsorbent for the analysis of organic and inorganic pollutants. Journal of hazardous materials. 2014;264:481-489.

15. M Oves., M Arshad., M. S Khan., A.S Ahmed., A Azam., I. M. I Ismail. Anti-microbial activity of cobalt doped zinc oxide nanoparticles: Targeting water borne bacteria. Journal of Saudi Chemical Society. 2015;195):581-588.

16. A Jilani., M. H. D Othman., M. O Ansari., M Oves., A Alshahrie., I. U Khan. A simple route to layerby-layer assembled few layered graphene oxide nanosheets: optical, dielectric and antibacterial 
aspects. Journal of Molecular Liquids. 2018;253:284-296.

17. M Oves., M Shahadat., S. A Ansari., M Aslam., I. I. M Ismail. Polyaniline Nanocomposite Materials for Biosensor Designing. Electrically Conductive Polymers and Polymer Composites: From Synthesis to Biomedical application, John Wiley \& Sons. 2018;113.

18. A. A. P Khan., A Khan., M. M Rahman., A. M Asiri., M Oves. Chemical sensor development and antibacterial activities based on polyaniline/gemini surfactants for environmental safety. Journal of Polymers and the Environment. 2018;26(4):1673-1684.

19. M Amil Usmani., I Khan., A. H Bhat., R. S Pillai., N Ahmad. Current trend in the application of nanoparticles for waste water treatment and purification: A review. Current Organic Synthesis. 2017;14(2):206-226.

20. M. Z Khan., M Shahadat., H. A Qari., I. I. M Ismail., Z. A Shaikh., M Oves. Pollutant Decontamination from Water: Role of Nanocomposite Materials. Enhancing Cleanup of Environmental Pollutants. 141-182.

21. M Arsalan., F Alam., I Khan., M Oves. Synthesis and characterization of $\mathrm{Co3}$ (Po4) 2 and Ni3 (Po4) 2 composite membranes based on PVC: A Comparative electrochemical studies through aqueous electrolyte solutions. Journal of Membrane Science and Research. 4(1);41-50.

22. A. A. P Khan., A Khan., M. M Rahman., A. M Asiri., M Oves. Sensor development of 1, 2 dichlorobenzene based on polypyrole/Cu-doped ZnO (PPY/CZO) nanocomposite embedded silver electrode and their antimicrobial studies. International journal of biological macromolecules. 98;256-267.

23. R Kumar., M Oves., T Almeelbi., N. H Al-Makishah., M. A Barakat. Hybrid chitosan/polyanilinepolypyrrole biomaterial for enhanced adsorption and antimicrobial activity.Journal of colloid and interface science. 490, 488-496. 